\title{
SEXUAL REHABILITATION AFTER CORD INJURY
}

\author{
By R. W. Jackson, M.D., M.S., F.R.C.S.(C.) \\ Toronto General Hospital, Toronto, Canada
}

\section{INTRODUCTION}

IN my administrative capacity as Chairman of the Canadian Wheelchair Sports Association (and not because I am an orthopaedic surgeon), I have been made aware of an area in which the medical profession has generally failed to provide adequate counselling to patients with spinal cord injuries. This is the area of sexual rehabilitation. Although numerous articles have been written on the altered physiology of sexual function after cord injury (Munro et al., I948; Talbot, I949; Bors, I963), on the genito-urinary problems involved (Horne et al., I948; Munro et al., I948; Talbot, I949; Bailey, I968; Cibeira, I970), on social studies dealing with marriage and divorce (Comarr, I962; Guttman, 1964), on statistical reviews of sexual competence (Talbot, 1949; Bors, 1963; Bailey, 1968; Cibeira, 1970; Jacobson, 1970) and on the psychological aspects of sex after cord injury (Berger et al., 1952; Money, 1960; Weiss et al., 1966; Frankel, 1967; Puth, I967; Bailey, 1968)-little has actually been written on the practical aspects of sex. It is the practical aspects that the average newly injured individual wants to know. $\mathrm{He}$ is not interested in statistics because he does not regard himself as a statistic. He does not know what the future holds for him, and frequently is afraid or too self-conscious to ask. In many instances his doctor is unable to advise him, either because the doctor himself does not know, or because he is inhibited in a Victorian way about discussing the practical aspects of sex.

Rehabilitation counsellors and social workers have therefore assumed much of the sexual counselling, and have expressed a need for a paper which reviews in relatively simple terms the scientific knowledge already accumulated on the subject, and which supplies basic information on how to achieve the maximum sexual activity possible, compatible with the degree of pathology.

This paper attempts, therefore, to review and summarise the pertinent previous literature and to add some practical points gained by survey and discussion with a group of tetraplegic and paraplegic athletes, who by virtue of their competition in National Wheelchair Games could be considered almost, if not fully, physically rehabilitated.

\section{REVIEW OF LITERATURE}

Bors in 1963 reported that 80 per cent. of male paraplegics and tetraplegics are capable of erection, with erections occurring more frequently in the higher lesions. Talbot in I949 reported that 75 per cent. of high lesions and 53 per cent. of lumbar and sacral lesions could achieve reflex erections only (that is following tactile stimulation) while another 2I per cent. of his total group of patients could also achieve erection by psychic (or mental) stimuli. The onset of erections was usually coincident with the emergence from spinal shock, and in some individuals 
was as early as 24 hours after injury. Although there were exceptions, if no erection occurred within six months, Talbot concluded that this ability would probably not return. In some instances however, erections did not commence until as late as two years after injury.

Bailey, in I968, reported that 30 per cent. of men were capable of intercourse with a slightly higher percentage in the partial or low lesions. Bors reported that although 50 per cent. of his group were capable of coitus, only i 5 per cent. were capable of ejaculation and approximately a similar percentage experienced orgasm. These figures are confirmed by other studies which showed coitus possible in 23-33 per cent., ejaculation in 3-19 per cent. and orgasm in 3-I8 per cent. of individuals. Sexual function was naturally better in low lesions or partial lesions.

The ability to conceive children is markedly reduced, however, with statistics showing that only I-5 per cent. of male paraplegics can produce progeny. This ability does not appear to be directly related to fertility, as Guttman in 1960 demonstrated that 50 per cent. of a group of paraplegics and tetraplegics were not sterile, and Horne, Paull and Monroe concluded in 1948, after collection of spermatozoa following electrical stimulation, 'that traumatic injury of the spinal cord does not in itself preclude fertility'. Although most recorded instances where progeny were produced occurred in incomplete lesions, there are instances where individuals with complete lesions have sired children (Horne et al., I948; Bors et al., 1963).

When an individual is sterile, it could be due to impaired spermatogenic function (Stemmerman et al., 1950) secondary to sympathetic denervation and loss of testicular temperature regulation, due to hormonal changes (Bors et al., I950), or in some instances possibly due to retrograde ejaculations.

If skeletal muscle spasms are severe, it would appear preferable to treat the spasms solely by the tranquilising drugs currently available. In the past, surgical or injection procedures frequently resulted in the abolishment of reflex sexual function (Talbot, 1949; Bors, I963).

A survey of the marital status of patients admitted to Stoke Mandeville (Guttman, I964), showed almost half the individuals to be married with a subsequent divorce rate of only $7 \cdot 3$ per cent. Comarr in 1962, showed a higher divorce rate amongst patients in the United States, with 27-39 per cent. being divorced after injury (Comarr, I962). This, however, was still lower than the overall divorce rate for California where almost half of all marriages are subsequently dissolved. The usual reasons for divorce were diverse, and included incompatibility, mental instability, immaturity, and in only a few instances, sexual frustration (Guttman, 1964). In most instances where divorce occurred after injury in a previously married couple, close examination showed the relationship to be dissolving prior to the injury, and divorce might have occurred in any case.

Survey of Male Athletes-Canadian Wheelchair Sports Association. A small sample of male athletes were surveyed by questionnaire and interview during competition at National Games (Table I). Although the averages for this group corresponded well with other published statistics, it was noted 75 per cent. of these fully rehabilitated individuals were able to engage in intercourse.

Spasms were generally not a problem in these active males, and there appeared to be little difference in sexual performance between complete and incomplete lesions. 
TABLE I

Survey of Male Athletes

\begin{tabular}{|c|c|c|c|c|}
\hline $\begin{array}{l}\text { Lesion level } \\
\text { (both complete and incomplete) }\end{array}$ & Cervical & $\begin{array}{l}\text { Thoracic } \\
\text { TI }_{I} \mathrm{~T}_{9}\end{array}$ & $\begin{array}{l}\text { Thoraco-lumber } \\
\text { Tio and below }\end{array}$ & $\begin{array}{l}\text { Averages } \\
\text { and totals }\end{array}$ \\
\hline No. of men & 4 & 7 & 9 & 20 \\
\hline $\begin{array}{l}\text { Time after injury } \\
\text { Average }\end{array}$ & $\begin{array}{l}3-15 \mathrm{yr} . \\
\mathrm{I} 2 \mathrm{yr} .\end{array}$ & $\begin{array}{l}\text { I-I I yr. } \\
4 \text { yr. }\end{array}$ & $\begin{array}{l}\text { 2-29 yr. } \\
\text { I } 4 \mathrm{yr} \text {. }\end{array}$ & $\begin{array}{l}\text { I-29 yr. } \\
\text { I0.7 yr. }\end{array}$ \\
\hline $\begin{array}{l}\text { Marital status } \\
\text { Married } \\
\text { Single } \\
\text { Divorced }\end{array}$ & $\begin{array}{l}\text { I } \\
3 \\
0\end{array}$ & $\begin{array}{l}4 \\
3 \\
0\end{array}$ & $\begin{array}{l}5 \\
2 \\
2\end{array}$ & $\begin{array}{l}50 \% \\
40 \% \\
10 \%\end{array}$ \\
\hline $\begin{array}{l}\text { Erections } \\
\text { on physical stimulus } \\
\text { on mental stimulus }\end{array}$ & $\begin{array}{l}4 \\
2\end{array}$ & $\begin{array}{l}5 \\
0\end{array}$ & $\begin{array}{l}8 \\
3\end{array}$ & $\begin{array}{l}85 \% \\
25 \%\end{array}$ \\
\hline $\begin{array}{l}\text { Intercourse } \\
\text { Before injury } \\
\text { After injury }\end{array}$ & $\begin{array}{l}4 \\
3\end{array}$ & $\begin{array}{l}6 \\
4\end{array}$ & $\begin{array}{l}8 \\
8\end{array}$ & $\begin{array}{l}90 \% \\
75 \%\end{array}$ \\
\hline Ejaculation & I & 3 & 3 & $35 \%$ \\
\hline Orgasm & I & 2 & 4 & $35 \%$ \\
\hline Conceived children & o & I & I & $10 \%$ \\
\hline $\begin{array}{l}\text { Urinary problems relating to } \\
\text { sex }\end{array}$ & 0 & I & I & $10 \%$ \\
\hline
\end{tabular}

\section{Practical Aspects of Sexual Function}

Erections. If psychic stimulation does not result in tumescence of the penis, manual stimulation of the male genitals is usually successful. When engorgement has been achieved, it can be maintained, if necessary by application of a gentle constricting device at the base of the penis. A rubber doughnut slipped over the penis may suffice (Reuben, I969), or a condom stretched around the base and held with elastoplast (stretch tape) is also useful. This tourniquet effect can maintain engorgement for as long as is desired. Needless to say it should not be applied too tightly, or left on too long (one half-hour should be considered maximum).

Commercially available devices reported to induce and maintain erections through electrical stimulation via the rectum or base of penis are not recommended, and usually not necessary.

Priapism, which is defined as 'persistent abnormal erection of the penis without sexual desire', is more common in the higher, more severe cord injuries. Quadriplegics may often initiate erection by reflex means, and maintain the 
erection for a very prolonged period of time. Some quadriplegics have therefore gained a measure of prominence in sex by being able to satisfy one or more women over a prolonged period of time without loss of erection.

Although it has been considered and possibly tried in some instances, most of the artificial means of producing a permanent erection are of no value. Injection of silicone into the penis or the surgical implantation of a permanently rigid substance is both dangerous on medical grounds and usually not necessary.

Positions for Intercourse. Several positions are possible. Quadriplegics usually are supine with the female partner on top and providing the activity. Paraplegic patients are usually able to assume top, bottom or side positions and activity of course depends on the neurological level. The usual precautions to prevent pressure sores must be taken.

Urinary Considerations in the Male. Unfortunately, many paraplegics have a chronic urinary tract infection (not syphilis or gonorrhoea), and there is considerable risk of infecting a sexual partner. It is therefore a practical point that careful washing of the penis, and voiding prior to intercourse should be practised. Although it is not essential to remove an indwelling catheter, the male may experience difficulty due to traction on the catheter and subsequent aggravation of an infection. If a condom catheter is used, it should be removed prior to intercourse and replaced afterwards. Too much activity during intercourse may result in loss of engorgement of the penis and possible urination into the vagina, especially after transurethral resection. In most instances, the urge to urinate is indicated by spasms and the individual is able to withdraw in time to avoid this unpleasant situation.

Frequency. As with the normal population, it is possible for a paraplegic to have intercourse as often as once or twice a week depending on his sexual appetite. Amongst those interviewed, it was felt that patients who had experienced sexual relations before damage to their spinal cord were more aggressive than those who were injured early in life, before they had any opportunity to experience sex. Those injured early in life tended not to know what to do or what to expect.

Satisfaction of Female Partner. Although artificial devices such as phallic substitutes can be purchased (Reuben, I969), most of the paraplegics interviewed did not use such objects for psychological reasons, regarding them as a type of perversion. Generally they preferred to satisfy their partner by hand or oral stimulation (again depending on psychological acceptance) in order to produce an orgasm in the female partner.

Female Paraplegics. A female paraplegic who is still menstruating can of course conceive and give natural birth to children (Guttman, I964; Comarr, 1966). In this respect her sexual function is unchanged after injury. In complete lesions there is of course, no sensation in the vagina, and although there may be some emotional satisfaction from intercourse, there is little in the way of physical satisfaction. Few women experience orgasm and it is doubtful whether a true physiological orgasm can occur in the female complete lesion. Faking of orgasm, 
however, is fairly common-possibly due to a desire to satisfy the male partner or for personal psychological reasons. In many instances oral intercourse is practised, again depending on the psychological acceptance of such a method.

During intercourse, the female usually assumes the supine position and it is not necessary for her catheter to be removed.

Artificial Insemination. In a marital situation, where both parties are desirous of the female bearing a child, artificial insemination can be practised. Unfortunately, few donors are available and few doctors are willing to become involved in this area due to significant legal and religious problems (Hefley et al., I970). However, several sperm banks have been established in the United States where human sperm is frozen and treated in the same fashion as bull sperm. When used, genetic qualities are matched as closely as possible and often a pooled specimen from at least three donors is implanted into the women.

Psychological Aspects. It is not the purpose of this paper to explore the psychological aspects of sex, which are varied, highly personal and complicated.

Bailey (I968) has recently stressed that the psychological aspects of sexual counselling are as equally important as the physiological and anatomical aspects, and both the patient and the partner require this counselling. The importance of this is emphasized by the following quotation by Puth (I967) which reads, 'Only a small part of sex relates to physical factors and intercourse. By far, the greatest part deals with playing the respective role of being a boy or a girl, a man or a woman, a husband or a wife-key sexual roles that go far beyond the biological factors of sex and constitute a way of life more than a bedroom experience.'

It is in this area of social and psychological adjustment that the rehabilitation counsellor has a major role to play. He should be armed, however, with factual and practical information provided by the medical profession and written in such a way that a lay person can understand. Perhaps then, he can intelligently answer the most frequently asked questions 'Can I have intercourse?', and 'Can I have children?'

\section{REFERENCES}

BaIley, J. A. (1968). Altered sex function and spinal cord injury. 5th International Congress of Physical Medicine. M.D. Magazine.

Berger, S. \& GARRETT, J. F. (I952). Psychological problems of the paraplegic patient. F. Rehabilitation, series 2 10.

Bors, E. (1963). Sexual function in patients with spinal cord injury. Proceedings of a Symposium on Spinal Injuries. Royal College of Surgeons of Edinburgh. Book, pub. 1967.

Bors, E., Engle, E. T., Rosenquist, R. C. \& Holliger, V. A. (1950). Fertility in paraplegic males. A preliminary report of endocrine studies. F. Clin. Endocrinology, 1o, $38 \mathrm{I}$.

Cibeira, J. B. (1970). Some conclusions on a study of 365 patients with spinal cord lesions. Paraplegia, 7, 249-254.

ComarR, A. E. (I962). Marriage and divorce among patients with spinal cord injury. Proceedings of I Ith Annual Spinal Cord Injury Conference. Vol. I I, pp. I63-2I 5.

ComarR, A. E. (I966). Interesting observations on females with spinal cord injury. Med. Services f. 22, 7 .

Frankel, A. (1967). Sexual problems in rehabilitation. F. Rehabilitation, vol. 33, pp. 19-20.

GutTMAN, L. (1960). The sexual problem in spinal paraplegia. Scientific Meeting. Stoke Mandeville Games, 65-69. 
Guttman, L. (1964). The married life of paraplegics and tetraplegics. Paraplegia, 2, I82.

HaRdY, A. C. \& WARrell, D. W. (1965). Pregnancy and labour in complete tetraplegia. Paraplegia, 3.

Hefley, J. C. \& Hefley, M. (1970). Babies in question. Todays Health, vol. 48.

Horne, H. W., Paull, D. P. \& Munro, D. (I948). Fertility studies in human male with traumatic injuries of spinal cord and cauda equina. New England F. Med. 239.

Jacobson, S. A. \& Bors, E. (I970). Spinal cord injury in Vietnamese combat. Paraplegia, 7.

MoNEY, J. (I960). Phantom orgasm in the dreams of paraplegic men and women. Archives of General Psychiatry, 3, 373.

Munro, D., Horne, H. W. \& Paull, D. P. (1948). The effect of injury to the spinal cord and cauda equina on the sexual potency of men. New England F. Medicine, 239, 903.

Puth, A. D. (1967). Quoted in F. Rehabilitation, 20.

REUBEN, D. Everything you always wanted to know about sex. Book, I969, pub. David McKay Co. Inc., N.Y.

Stemmerman, G. N., Weiss, L., Auerbach, O., \& Friedman, M. (1950). A study of the germinal epithelium in male paraplegics. Amer. F. Clinical Pathology, 20, 24-34.

TALBOT, H. S. (1949). A report on sexual function in paraplegics. F.Urol. 6r, 2.

WEISS, A. J. \& DiAMOND, M. D. (1966). Sexual adjustment, identification and attitudes of patients with myelopathy. Archives of Physical Medicine and Rehabilitation, 47, 245. 